\title{
Guano deposition and nutrient enrichment in the vicinity of planktivorous and piscivorous seabird colonies in Spitsbergen
}

\author{
Adrian Zwolicki • Katarzyna Małgorzata Zmudczyńska-Skarbek • \\ Lech Iliszko • Lech Stempniewicz
}

Received: 9 January 2012/Revised: 6 November 2012/Accepted: 8 November 2012/Published online: 28 November 2012 (C) The Author(s) 2012. This article is published with open access at Springerlink.com

\begin{abstract}
The crucial role of seabirds in the enrichment of nutrient-poor polar terrestrial ecosystem is well-known. However, no studies have examined the potentially different impacts associated with piscivorous and planktivorous bird colonies on the surrounding tundra soils. Therefore, we compared guano deposition and physical and chemical parameters of soil near two large seabird colonies, one of planktivorous little auks (Alle alle) and the other comprising piscivorous Brunnich's guillemots (Uria lomvia) and kittiwakes (Rissa tridactyla). The two colonies generated similar levels of guano deposition, with the intensity of deposition decreasing away from the colony. Guano deposition adjacent to both colonies was considerably higher than that in control areas. The increased guano supply around colonies significantly enhanced soil conductivity, nitrogen $\left(\mathrm{NO}_{3}{ }^{-}, \mathrm{NH}_{4}{ }^{+}\right)$, potassium $\left(\mathrm{K}^{+}\right)$, and phosphate $\left(\mathrm{PO}_{4}{ }^{3-}\right)$ ion concentrations and led to reduced $\mathrm{pH}$ values. Guano deposition explained $84 \%$ (piscivorous colony) and $67 \%$ (planktivorous colony) of the total variation in the tested soil parameters. Planktivore and piscivore colonies affected adjacent tundra in different ways. The phosphate content and $\mathrm{pH}$ value of soil influenced by piscivores were significantly higher than values measured
\end{abstract}

\footnotetext{
A. Zwolicki $(\bowtie) \cdot$ K. M. Zmudczyńska-Skarbek · L. Iliszko ·

L. Stempniewicz

Department of Vertebrate Ecology and Zoology,

University of Gdańsk, Legionów 9, 80-441 Gdańsk, Poland

e-mail: adrian.zwolicki@ug.edu.pl

K. M. Zmudczyńska-Skarbek

e-mail: biozmud@ug.edu.pl

L. Iliszko

e-mail: biolil@univ.gda.pl

L. Stempniewicz

e-mail: biols@ug.edu.pl
}

in planktivore-influenced soil. The gradient of guano deposition and associated ion content in the soil decreased more rapidly with distance from the piscivore colony. Climate-induced changes in populations of planktivorous and piscivorous seabirds are expected in the study region and may therefore have substantial consequential effects on Arctic terrestrial ecosystems.

Keywords Arctic soil - Brunnich's guillemot . Kittiwake - Little auk - Ornithogenic tundra

\section{Introduction}

Birds that forage at sea and breed on land deposit large amounts of guano, eggshells, feathers, and carcasses near their colonies, thus initiating the formation of ornithogenic soils and thereby facilitating the development of associated tundra communities, with increased primary and secondary production and biodiversity (Mulder et al. 2011; Ellis et al. 2011). This large-scale transport of organic and inorganic matter from sea to land is crucial for many Arctic and Antarctic terrestrial ecosystems, which otherwise are characterized by chronic deficiency of certain nutrients such as nitrogen, phosphorus, potassium, and calcium (Ryan and Watkins 1989; Cocks et al. 1998; Stempniewicz 2005; Bokhorst et al. 2007; Smith and Froneman 2008).

The quantity of biogenic nutrients deposited by seabirds on tundra depends on their daily rate of excrement production, which is a function of the colony size, the length of time birds remain in a colony, the bird species, and their body size. Guano production and its composition are related to the diet, with different proportions of organic and non-organic fractions and particular mineral salts reported in analyses of the guano of plankton-, fish-, and bivalve- 
eating birds (Hutchison 1950; Galkina 1974; Bédard et al. 1980).

Guano deposition influences various physical and chemical soil parameters, such as concentration of ammonium, nitrate, phosphate, magnesium and potassium ions, as well as soil humidity, conductivity, and respiration rate (Gilham 1956; Ryan and Watkins 1989; Anderson and Polis 1999; García et al. 2002; Wait et al. 2005; Ellis et al. 2006). Although guano itself is typically alkaline, the process of its decomposition in the soil often results in increased soil acidity being found near seabird colonies (Gilham 1956; García et al. 2002; Ellis 2005; Wait et al. 2005).

The magnitude of guano deposition changes most obviously with the distance from bird colonies (or other concentrations of vertebrate activity). Highest levels are seen close to the colony, with levels decreasing with distance. This decreasing gradient is often oriented toward the coast, where fertilization through sea spray may become an additional or superimposed factor modifying soil characteristics (Gilham 1956; Ryan and Watkins 1989; Wainright et al. 1998; Bokhorst et al. 2007). Deposited guano is decomposed by microorganisms, and the proportion of biogenic nutrients made available to plants is therefore a balance between decomposition and leaching or outwash rates (Heal and French 1974; Stempniewicz 2005). The rate at which nutrients delivered to the colony area return to the sea depends among other factors on local topography, precipitation and water runoff, vegetation type and cover (Pulina 1984; Stempniewicz 1990, 2005). On High Arctic Svalbard, the two most common seabird colony types differ substantially in these respects. These are (1) coastal cliffs inhabited by Brunnich's guillemots (Uria lomvia) and kittiwakes (Rissa tridactyla), and (2) little auk (Alle alle) colonies usually situated on mountain slopes at a greater distance from the coast. Large and relatively diffuse colonies of planktivorous little auks are therefore likely to influence a greater area of tundra than the more defined colonies of piscivorous species situated on coastal rocky cliffs.

Current regional climate change models suggest that Arctic terrestrial ecosystems will be subject to both direct impact by climate warming and indirectly through the increasing influence of Atlantic waters (Stempniewicz et al. 2007). One outcome of this combination of environmental drivers will be to favor zooplankton communities based on smaller species with an increased representation of planktivorous fish and, consequently, piscivorous seabirds. Planktivorous seabirds, which prefer the larger and more energy-rich zooplankton associated with retreating cold Arctic waters, will therefore be at a disadvantage.

The food of little auks is comprised mostly of copepods (Calanus glacialis and C. hyperboreus in cold Arctic waters, and $C$. finmarchicus in warmer Atlantic waters)
(Stempniewicz 2001; Karnovsky et al. 2003; Jakubas et al. 2007). Guillemots and kittiwakes feed mainly on fish, such as polar cod (Boreogadus saida) and capelin (Mallotus villosus) (Brekke and Gabrielsen 1994; Mehlum et al. 1998; Mehlum 2001). These seabirds also differ in their typical behavior while on or over land, with little auks spending more time circling over and around the colony, and thereby likely to influence a different area of tundra to guillemots and kittiwakes (Stempniewicz et al. 2007). The diet and behavior of colonial seabirds may therefore also indirectly affect the surrounding Arctic tundra soil characteristics. For instance, the higher phosphate content in food of piscivorous, if it results in high levels of phosphate in their guano, may contribute to overcoming nutrient limitations in the soil developing near their colonies (Hutchison 1950; Galkina 1974; Breuning-Madsen et al. 2008). To date, no studies have examined the potentially different impacts associated with piscivorous and planktivorous Arctic bird colonies on surrounding tundra soils. Therefore, the aims of this study were to test the hypotheses that:

1. Ornithogenic tundra in the vicinity of planktivorous and piscivorous seabird colonies differs in soil physical and chemical properties.

2. Tundra fertilization and soil chemical characteristics change along the colony-sea gradients at different rates around the two colony types.

\section{Materials and methods}

\section{Study area}

The research took place in July 2005 and 2006, on the northern coast of Hornsund fjord (southwest Spitsbergen), in areas influenced by two large seabird breeding colonies (Fig. 1):

1. A colony of planktivorous little auks situated on Ariekammen mountain $\left(77^{\circ} 00^{\prime} \mathrm{N} 15^{\circ} 31^{\prime} \mathrm{E}\right)$ (Fig. 1a). The study area included the mountain slope (inclination $35-45^{\circ}$ ) flattening to almost horizontal tundra reaching the seashore (effectively a ca. 1,000 m transect).

2. A mixed colony of piscivorous Brunnich's guillemots and kittiwakes at the foot of Gnålberget mountain $\left(77^{\circ} 01^{\prime} \mathrm{N} 15^{\circ} 52^{\prime} \mathrm{E}\right)$ (Fig. 1b). The study area included the area between the rocky cliff inhabited by the birds and the ca. $500 \mathrm{~m}$ distant seashore. The talus slope decreased with the distance from the colony, with an inclination of $40-50^{\circ}$ directly under the cliff itself and almost horizontal ground near the coast. 




Fig. 1 Map of the study area and location of transects; a little auk colony and b Brunnich's guillemot and kittiwake colony

Both colonies are long-established and of similar size, each consisting of ca. 10,000 breeding pairs (Stempniewicz 1992; Isaksen 1995). Typical simple Arctic soils, mostly gleysols and regosols, occur in the study area, ranging in depth from 15 to $20 \mathrm{~cm}$ (Fischer and Skiba 1993). Plant communities occurring in these study areas are characteristic of well-fertilized bird-cliff vegetation (Rønning 1996), with vegetation cover typically $90-95 \%$ across the study areas, excepting the seashore itself and sites directly under the cliff inhabited by guillemots and kittiwakes, that were damaged mechanically by falling rocks. Well-developed vascular plants and algal mats predominated over mosses. The zonal character of vegetation along the colony-sea axis was clearly defined (Zmudczyńska et al. 2009; Wojtuń pers. comm.). Detailed descriptions of plant communities at the study locations are given by Zmudczyńska et al. (2012).

Two transects ('colony transects') were defined within both study areas, starting from the zone of the highest colony impact (center of the little auk colony and foot of the guillemot/kittiwake nesting cliff), running down the slope and ending on the seashore (Fig. 1). Both transects were oriented toward (exposed to) the southeast and covered an altitudinal range from sea level to ca. $200 \mathrm{~m}$ asl. The transects consisted of 10 (Gnålberget) and 12 (Ariekammen) sample plots $(160 \times 160 \mathrm{~cm})$. More plots were situated in the vicinity of each colony, where the greatest variety of vegetation zones was present, than in the more distant and homogenous coastal area. The little auk colony covered a large area of the relatively shallow slope and had a less clear-cut boundary than was the case for the cliffnesting species. This transect (ca. $1,000 \mathrm{~m}$ long) commenced from the colony center, while that for the guillemot and kittiwake colony (ca. $500 \mathrm{~m}$ long) commenced just beneath the nesting cliff; in both cases, we considered these points (sampling plot 1) as being the most influenced by seabirds. Subsequent sampling plots were located at increasing distance from the starting points, as follows: plot 2 (6 m), 3 (15 m), 4 (29 m), 5 (49 m), 6 (79 m), 7 (125 m), $8(193 \mathrm{~m}), 9(296 \mathrm{~m}), 10(449 \mathrm{~m}), 11(680 \mathrm{~m})$ and plot 12 $(1,026 \mathrm{~m})$ (the latter two plots only for the little auk colony). In both study areas, a control transect was defined in a topographically similar location but not under the routine flight route of the seabirds, hence experiencing much lower ornithogenic impact. Eleven (Gnålberget) or 12 (Ariekammen) plots were designated along the control transects following the principle described above. The transects situated in the Ariekammen study area were annotated P (planktivorous colony) and Pc (control transect), while those situated in the Gnålberget study area were annotated $\mathrm{F}$ (piscivorous colony) and Fc (control transect).

Guano deposition measurements

Along the colony and control transects guano deposition was assessed using black plastic sheets $(150 \times 150 \mathrm{~cm})$ placed next to each sampling plot. Their intended exposure time was $24 \mathrm{~h}$, but in few cases this was extended or shortened depending on weather conditions (range: 20-36 h). After exposure, a digital photograph of each sheet was taken (Canon PowerShot A95, resolution 5.0 million pixels). The sheets were cleaned before being re-exposed $(\mathrm{P}=6$ days total, $\mathrm{Pc}=6$ days, $\mathrm{F}=9$ days, $\mathrm{Fc}=1$ days). The guano covered area in each photograph was analyzed using SigmaScan Pro 5.0.0 software.

In order to provide an accurate estimate of guano deposition (dry mass) from the photographs obtained, we 
performed an initial calibration. We exposed stiff plastic sheets covered with very thin plastic film of known mass. After these sheets were exposed and photographed, the plastic films were removed, dried, and re-weighed to obtain dry mass. Regression equations were calculated for each study area separately (Ariekammen, $y=0.003 x$, $R^{2}=0.7, N=31$; Gnålberget, $y=0.008 x, R^{2}=0.7$, $N=10)$.

\section{Physical and chemical analyses of soil}

Soil samples were collected from three points lying on the same diagonal of each sampling plot (one from the center and two from the corners of the plot) $(N=123,13$ samples were lost during analyses). Samples were taken from the soil surface layer using a shovel to a depth of $10 \mathrm{~cm}$. Each sample contained about $500 \mathrm{~cm}^{3}$ of soil. Large stones were avoided or removed during sampling. Soil samples were prepared for analysis immediately after collection. Each sample was divided into three subsamples of $80 \mathrm{~cm}^{3}$ each, weighed to the nearest $0.1 \mathrm{~g}$ and the following were assessed:

1. Soil dry mass (\%) was measured by oven-drying $\left(60{ }^{\circ} \mathrm{C}\right)$ the sample until constant mass. The \% soil dry mass was calculated from the initial and final masses.

2. Soil conductivity $\left(\mu \mathrm{S} \mathrm{cm}{ }^{-1}\right)$ and $\mathrm{pH}$-Soil samples of $80 \mathrm{~cm}^{3}$ were mixed with $160 \mathrm{~cm}^{3}$ of distilled water. The mixture was shaken for ca. $20 \mathrm{~min}$ and then filtered through a sieve $(0.5 \mathrm{~mm}$ mesh). The conductivity and $\mathrm{pH}$ were quantified in the filtrate using a $\mathrm{pH} /$ conductivity/salinity meter CPC-401 (Elmetron).

3. Nitrogen $\left(\mathrm{NO}_{3}{ }^{-}\right.$and $\left.\mathrm{NH}_{4}{ }^{+}\right)$, potassium $\left(\mathrm{K}^{+}\right)$, and phosphate $\left(\mathrm{PO}_{4}{ }^{3-}\right)$ content $\left(\mathrm{mg} 1,000 \mathrm{~g}^{-1}\right.$ soil dry mass)-Soil samples of $80 \mathrm{~cm}^{3}$ were mixed with $200 \mathrm{~cm}^{3} 0.03 \mathrm{~N}$ acetic acid and left for ca. $60 \mathrm{~min}$ while being shaken regularly. The solution was then filtered through a sieve $(0.5 \mathrm{~mm}$ mesh $)$ and filter paper (MN $640 \mathrm{w}$, Macherey-Nagel $\Phi=125 \mathrm{~mm}$ ). The filtrate was analyzed using a photometer LF205 following standard procedures (Cygański 1994).

\section{Data analyses}

Spearman's rank correlation was used to examine the relationships between guano deposition and each physical and chemical variable separately for each colony using combined data from the colonial and control transects. Nonparametric analysis was used due to the non-normal distributions of data obtained and the relatively low number of sampling plots.
To describe relationship between guano deposition and distance from the colony, the piecewise regression function was performed separately for each colonial transect.

Redundancy analysis (RDA, linear direct gradient analysis) was performed in order to assess the impact of guano deposition on multivariate response of physical and chemical soil parameters. This used two separate models where each had a defined type of interaction: for the colony transect (Guano*Colony) and control transect (Guano*Control). After RDA, a Monte Carlo permutation test was performed (499 permutations) to identify which factors significantly influenced the model (ter Braak and Šmilauer 2002). Principal component analysis (PCA, linear indirect gradient analysis) was used to ordinate the soil parameters obtained from the four study transects. Dependent variables were log transformed to normalize them (ter Braak and Šmilauer 2002). The slope inclination was used as covariable in both ordination techniques.

Larger amounts of guano deposition were found close to the colonies, with smaller amounts and less differentiation on transect sectors near to the coast. Therefore, only data from the first six plots ( $0-80 \mathrm{~m}$ from the colony) of each transect were used in subsequent comparisons. In order to test for differences in each soil parameter value (median) between transects, the nonparametric Kruskal-Wallis and post hoc Dunn's tests were performed.

The results were processed using the STATISTICA 8.0 package for the regression, correlation, and variance analyses [StatSoft, Inc. (2008). STATISTICA (data analysis software system), version 8.0, www.statsoft.com] and the CANOCO 4.51 package for gradient ordination methods (ter Braak and Šmilauer 2002).

\section{Results}

Guano deposition

Guano deposition along both planktivorous (P) and piscivorous $(\mathrm{F})$ colony transects decreased significantly with increasing distance from the colony $\left(\mathrm{P}: r_{s}=0.85\right.$, $\left.p<0.001 ; \mathrm{F}: r_{s}=0.78, p<0.001\right)$. Guano deposition decreased much more abruptly near the piscivorous colony. The break point values identified by piecewise regression function were $316 \mathrm{~m}$ for the planktivorous colony and $48.8 \mathrm{~m}$ for the piscivorous colony (Fig. 2). Guano deposition close to both colonies (sample plots 1-6) was considerably higher $[\mathrm{P}: \mathrm{Me}=0.32 ; \mathrm{F}$ : $\mathrm{Me}=0.37$ $\left(\mathrm{g} \mathrm{m}^{-2}\right.$ day $\left.\left.^{-1}\right)\right]$ than in their respective control transects $\left[\mathrm{Pc}: \mathrm{Me}=0.002\right.$; Fc: $\mathrm{Me}=0.009\left(\mathrm{~g} \mathrm{~m}^{-2}\right.$ day $\left.\left.^{-1}\right)\right]$ (Kruskal-Wallis $\mathrm{H}_{3,125}=81.31, p<0.001$, post hoc Dunn's test $p<0.05)$. There was no difference in guano deposition 
per unit time or area between the two colonies transects $(\mathrm{P}$ vs. F, $p>0.05$ ) or between the two control transects (Pc vs. Fc, $p>0.05)$. However, the maximum value found (1.6 $\mathrm{g} \mathrm{m}^{-2} \mathrm{day}^{-1}$ ) was higher directly below the piscivorous colony than in the center of the planktivore colony (up to $1.2 \mathrm{~g} \mathrm{~m}^{-2}$ day $^{-1}$ ).

Physical and chemical soil gradients

There were well-defined relationships between most of the physical and chemical soil parameters and increasing distance from the colonies (Fig. 3; Table 1). The highest values were recorded close to both colonies $\left(\mathrm{NH}_{4}{ }^{+}=26.2 \mathrm{mg} 1,000 \mathrm{~g}^{-1}\right.$ of soil dry mass (P), $107.5 \mathrm{mg}(\mathrm{F}) ; \mathrm{NO}_{3}{ }^{-}=361.3 \mathrm{mg}(\mathrm{P}), 2,117.2 \mathrm{mg}(\mathrm{F})$; $\mathrm{K}^{+}=148.3 \mathrm{mg}(\mathrm{P}), 590.1 \mathrm{mg}(\mathrm{F}) ; \mathrm{PO}_{4}{ }^{3-}=99.8 \mathrm{mg}(\mathrm{P})$, 4,191.2 mg (F)) (Fig. 3a-h; Table 1). The subsequent rate of change away from the colonies was again much greater around the piscivore colony and was especially evident in the phosphate ion concentration (Fig. $3 \mathrm{~g}, \mathrm{~h}$ ). Concentration of the $\mathrm{NO}_{3}{ }^{-}$ion $\left(\mathrm{P}: r_{s}=-0.55\right.$, Fig. 3c; F: $r_{s}=-0.89$, $p<0.05$; Fig. $3 \mathrm{~d}$ ) and soil conductivity (P: $r_{s}=-0.64$, Fig. 3k; F: $r_{s}=-0.68, p<0.05$, Fig. 31) significantly decreased, while $\mathrm{pH}$ value increased (P: $r_{s}=0.59$, Fig. 3i; $\mathrm{F}: r_{s}=0.62, p<0.05$, Fig. $\left.3 \mathrm{j}\right)$ with increasing distance
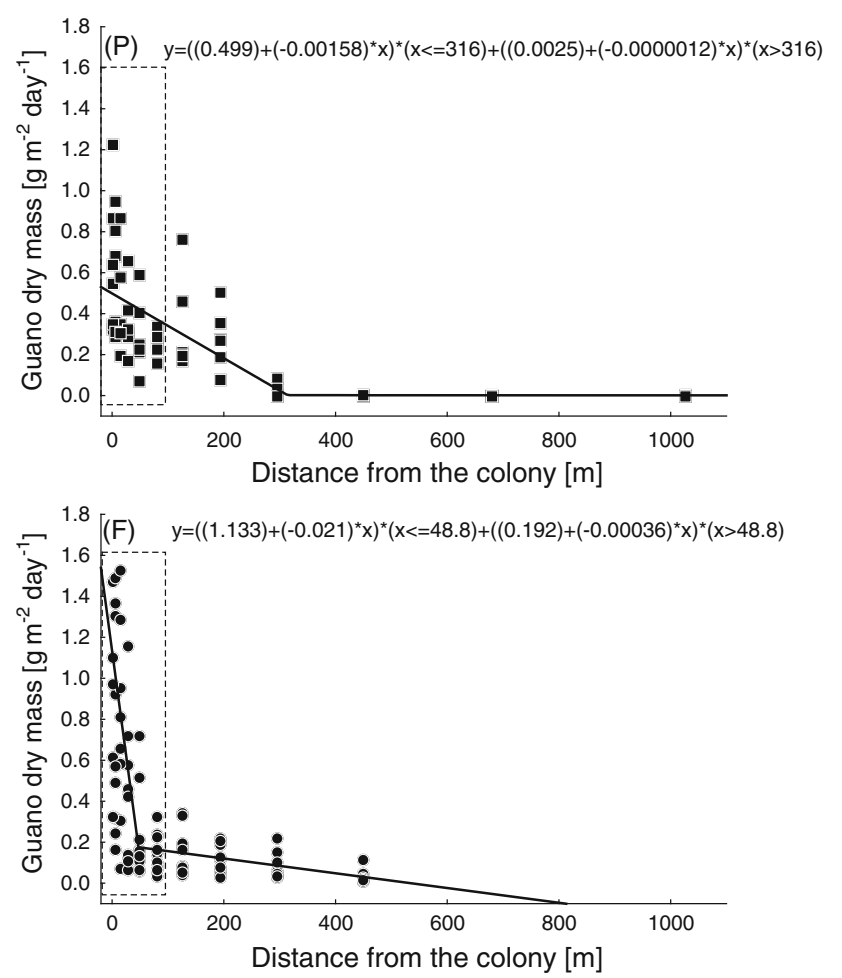

Fig. 2 Piecewise regression relationship between guano deposition rate (dry mass $\mathrm{g} \mathrm{m}^{-2} \mathrm{day}^{-1}$ ) and distance from the colonies $(\mathrm{m})$ of (P) planktivorous and (F) piscivorous seabirds. Plots 1-6 are marked with a dashed line from both colonies. A strong negative correlation of phosphate ion concentration $\left(\mathrm{PO}_{4}{ }^{3-}, r_{s}=-0.94, p<0.05\right.$, Fig. 3h) and soil dry mass $\left(r_{s}=-0.79, p<0.05\right.$, Fig. 3n) was found with increasing distance from the piscivore colony (F). Similarly, ammonium ion $\left(\mathrm{NH}_{4}{ }^{+}\right)$concentration $\left(r_{s}=-0.49, p<0.05\right.$, Fig. 3a) and also soil dry mass $\left(r_{s}=-0.49, p<0.05\right.$, Fig. $\left.3 \mathrm{~m}\right)$ decreased significantly away from the planktivore colony (P). No significant relationships were identified for $\mathrm{K}^{+}$concentration for either colony (Fig. 3e, f; Table 1).

Soil response to guano deposition

Guano deposition was a good predictor for all tested soil parameters within the two colony transects but not their control transects (Monte Carlo permutation test). Near the piscivore colony, the Guano*Colony $[F]$ interaction explained $84 \% \quad(F=37.3, p=0.002)$, and near the planktivore colony, the Guano*Colony $[P]$ interaction explained $67 \%(F=13.6, p=0.004)$ of the total soil physicochemical variability. Guano deposition along the control transects was insignificant for both tested models (Guano ${ }^{*}$ Control $[F]: F=1.0, p=0.32$; Guano ${ }^{*}$ Control $[P]: F=1.93, p=0.18$ ) (Fig. 4).

In both study areas, the concentrations of all analyzed ions significantly increased, while $\mathrm{pH}$ values decreased, with increasing guano deposition ( $\left|r_{s}\right|$ values ranged from 0.62 to $0.90 ; p<0.05$; Table 2 ). In the case of conductivity, a significant positive correlation was found only near the piscivore colony $\left(r_{s}=0.87, p<0.05\right)$. Soil dry mass was negatively correlated with guano deposition near the planktivore colony $\left(r_{s}=-0.58, p<0.05\right)$, with the relationship near the piscivore colony not being significant (Table 2).

Planktivorous and piscivorous seabird impact comparison

Patterns of variation in the soil physical and chemical parameters in relation to guano deposition were distinct between the study transects. The PCA ordination based on soil physicochemical properties showed that all the samples formed four separate aggregations reflecting their source transects (Fig. 5). The first ordination axis represented differentiation with respect to the colony impact and explained $64.7 \%$ of the total variability. Samples grouped on the right side of the diagram originated from the colony transects. They were characterized by higher concentrations of all tested ions and conductivity, and lower values of $\mathrm{pH}$ and soil dry mass. All samples collected from control transects are situated on the left side of the diagram. The relatively higher dispersion of samples from both colony transects supports higher variability in the tested 

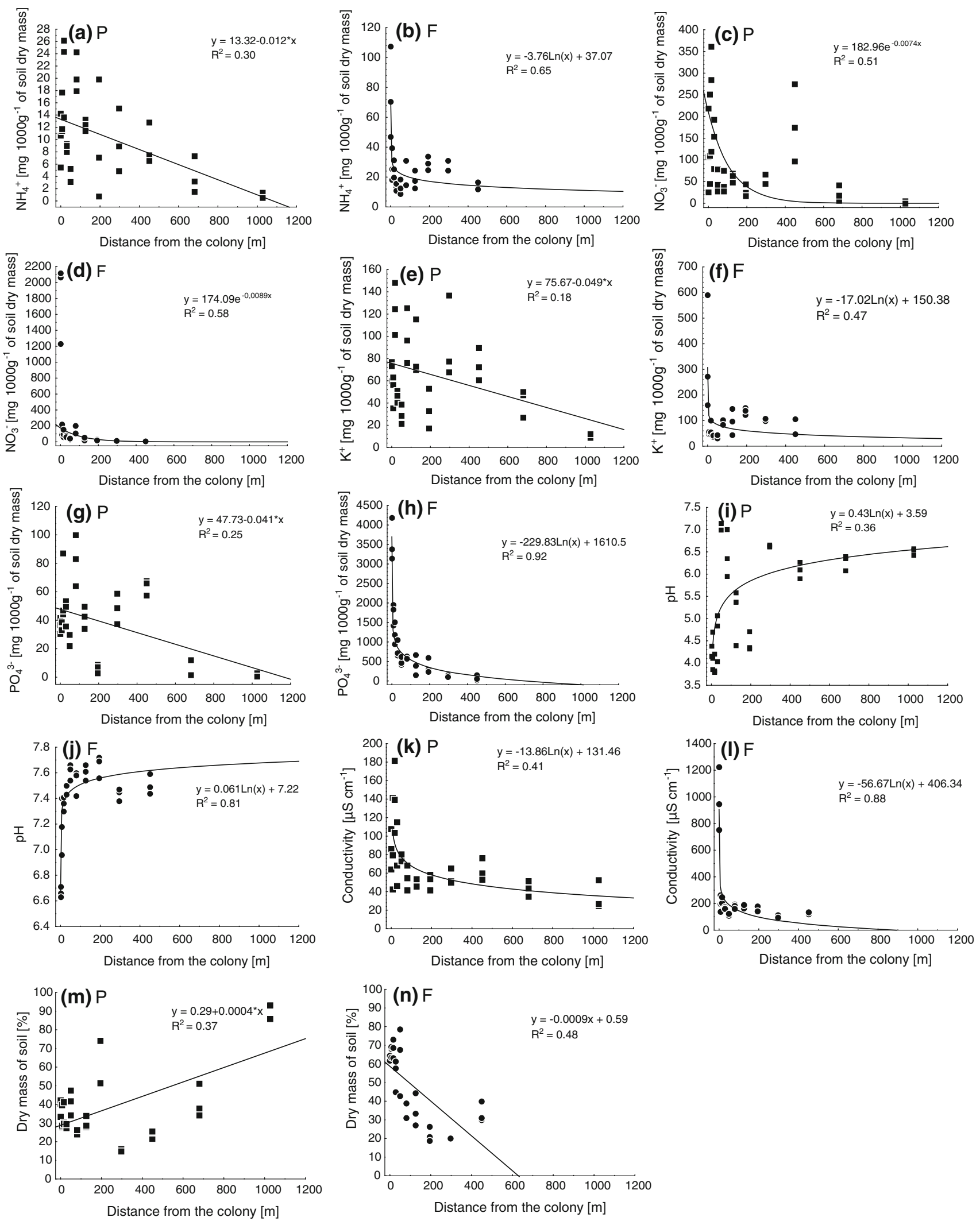

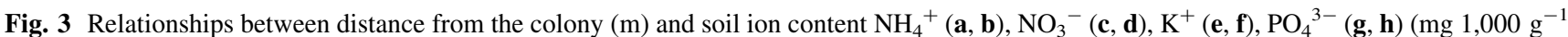
soil dry mass), $\mathrm{pH}(\mathbf{i}, \mathbf{j})$, conductivity $\left(\mu \mathrm{S} \mathrm{cm} \mathrm{cm}^{-1}, \mathbf{k}, \mathbf{l}\right)$ and soil dry mass $(\%, \mathbf{m}, \mathbf{n})$ on the planktivorous $(\mathrm{P})$, and piscivorous colony transects $(\mathrm{F})$ 
Table 1 Relationships between distance from the colony $(\mathrm{m})$ of planktivorous little auks $(\mathrm{P})$ and piscivorous guillemots and kittiwakes $(\mathrm{F})$ with soil ion content ( $\mathrm{mg} 1,000 \mathrm{~g}^{-1}$ soil dry mass), $\mathrm{pH}$, conductivity $\left(\mu \mathrm{S} \mathrm{cm}^{-1}\right)$, and dry mass $(\%)$

\begin{tabular}{lllllllll}
\hline Transect & $N$ & $\mathrm{NH}_{4}{ }^{+}$ & $\mathrm{NO}_{3}{ }^{-}$ & $\mathrm{K}^{+}$ & $\mathrm{PO}_{4}{ }^{3-}$ & $\mathrm{pH}$ & Conductivity & Dry mass \\
\hline $\mathrm{P}$ & 36 & -0.49 & -0.55 & $\mathrm{~ns}$ & $\mathrm{~ns}$ & 0.59 & -0.64 & $\mathrm{~ns}$ \\
$\mathrm{~F}$ & $27-30$ & $\mathrm{~ns}$ & -0.89 & $\mathrm{~ns}$ & -0.94 & 0.62 & -0.68 & -0.79 \\
\hline
\end{tabular}

$n s$ no significant correlation $(p>0.05)$
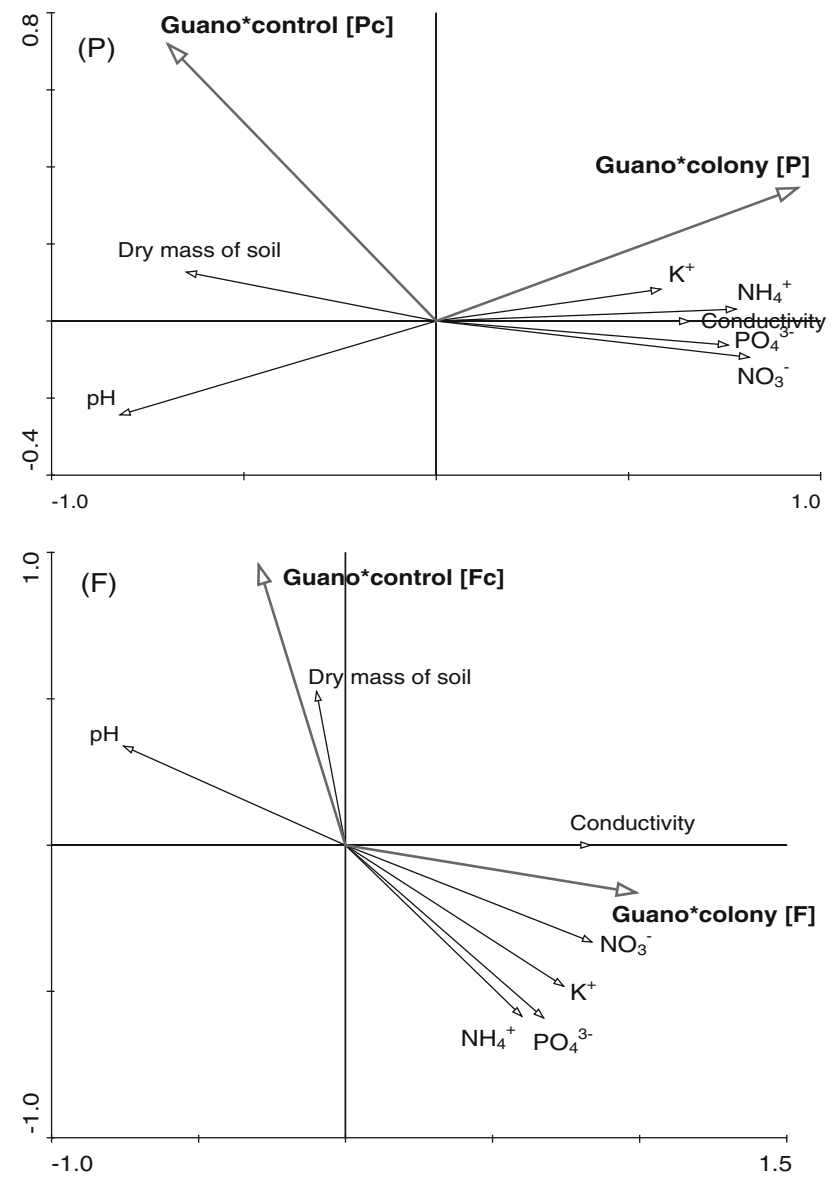

Fig. 4 Redundancy analysis (RDA) of soil ion content (mg $1,000 \mathrm{~g}^{-1}$ soil dry mass), $\mathrm{pH}$, conductivity $\left(\mu \mathrm{S} \mathrm{cm}^{-1}\right)$, and dry mass of soil (\%) (log transformed) with guano deposition rate (dry mass $\mathrm{g} \mathrm{m}^{-2}$ day $^{-1}$ ) on colony and control transects. $P$ planktivore colony, $F$ piscivore colony

parameters. The second ordination axis, explaining $17.7 \%$ of variability, separates the different colony types (Fig. 5).

Significantly higher concentrations of all four ions were observed on both colony transects as compared to their respective controls (Kruskal-Wallis' test, $p<0.001$; post hoc Dunn's test $p<0.05$, Table 3). For example, the median phosphate ion content was $627.74 \mathrm{mg} 1,000 \mathrm{~g}^{-1}$ soil dry mass within the piscivore-influenced area and only $0.7 \mathrm{mg} 1,000 \mathrm{~g}^{-1}$ of soil dry mass within its respective control area. Soil $\mathrm{pH}$ was significantly lower $(p<0.05)$ on the planktivore transect $(\mathrm{Me}=5.74)$ than on its control
$(\mathrm{Me}=7.20)$. No significant difference for this parameter was observed between $\mathrm{F}$ and $\mathrm{Fc}$ transects. Soil dry mass values were ca. twofold lower on control transects than on their respective colony transects $(p<0.05)$. Significant differences between the two colony transects included higher concentration of phosphate, higher $\mathrm{pH}$, conductivity, and soil dry mass near the piscivore than the planktivore colony ( $p<0.05$, Table 3 ). No significant differences were detected between the two control transects in most analyzed parameters, excepting $\mathrm{pH}$ and conductivity $(p<0.05$, Table 3).

\section{Discussion}

Our study documents the clear impact of guano deposited by seabirds in the vicinity of their breeding colonies on the chemical and physical parameters of Arctic tundra soil on Spitsbergen. Tundra fertilization was much greater adjacent to colonies, and gradually decreased along the colonysea axis, reaching values similar to those found on control transects near to the coast.

Both types of colonies are continuously occupied by breeding birds from June to August. The nesting period for little auks lasts about 28 days (Gaston and Jones 1998; Stempniewicz 2001; Strøm 2005), whereas for Brunnich's guillemots and kittiwakes, it lasts 20-22 and 35-40 days, respectively (Brekke and Gabrielsen 1994; Strøm 2005). These two colonies studied were similar in size, numbering around ten thousand breeding pairs each (Stempniewicz 1992; Isaksen 1995). Little auks, guillemots, and kittiwakes differ in body mass (kittiwake: $366 \pm 35 \mathrm{~g}$, Brunnich's guillemot: $967 \pm 54 \mathrm{~g}$, little auk: $163 \pm 11 \mathrm{~g}$; Brekke and Gabrielsen 1994; Gaston and Jones 1998; Stempniewicz 2001; Strøm 2005) and almost certainly produce different amounts of guano per day. Despite this, the median rates of guano deposition (dry mass $\mathrm{g} \mathrm{m}^{-2}$ day $^{-1}$ ) on tundra adjacent to the two colonies were similar.

Nutrient-rich guano deposited on tundra was the most important factor influencing the physico-chemical parameters of the soil and explains the greatest proportion of their total variability. Increased soil conductivity and concentrations of nitrogen $\left(\mathrm{NO}_{3}{ }^{-}, \mathrm{NH}_{4}{ }^{+}\right)$, potassium $\left(\mathrm{K}^{+}\right)$, and phosphate $\left(\mathrm{PO}_{4}{ }^{3-}\right)$ ions, as well as soil acidification, were 
Table 2 Spearman's rank correlation coefficient $\left(r_{s} ; p<0.05\right)$ between guano deposition rate (dry mass $\mathrm{g} \mathrm{m}^{-2}$ day $^{-1}$ ) and soil ion content (mg 1,000 $\mathrm{g}^{-1}$ soil dry mass), $\mathrm{pH}$, conductivity $\left(\mu \mathrm{S} \mathrm{cm}^{-1}\right)$,

\begin{tabular}{lllllllll}
\hline Study area & $N$ & $\mathrm{NH}_{4}{ }^{+}$ & $\mathrm{NO}_{3}{ }^{-}$ & $\mathrm{K}^{+}$ & $\mathrm{PO}_{4}{ }^{3-}$ & $\mathrm{pH}$ & Conductivity & Dry mass \\
\hline Plankton-eaters & 24 & 0.75 & 0.62 & 0.72 & 0.67 & -0.76 & $\mathrm{~ns}$ & -0.59 \\
Fish-eaters & 17 & 0.69 & 0.90 & 0.81 & 0.78 & -0.71 & 0.87 & $\mathrm{~ns}$
\end{tabular}

$n s$ no significant correlation $(p>0.05)$

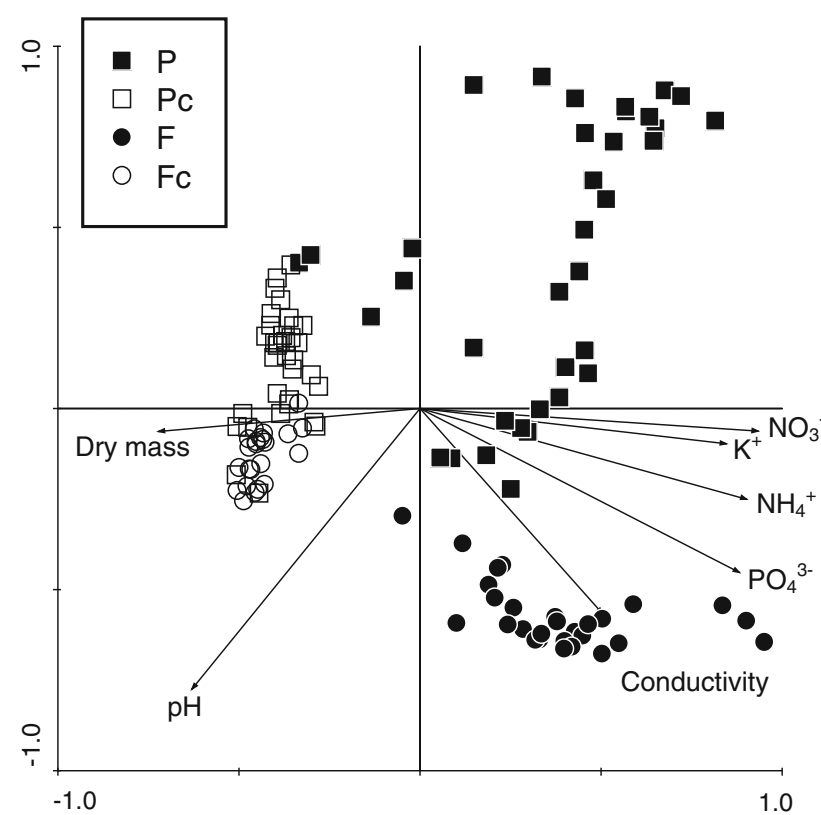

Fig. 5 Principal component analysis (PCA) of soil ion content (mg $1,000 \mathrm{~g}^{-1}$ soil dry mass), $\mathrm{pH}$, conductivity $\left(\mu \mathrm{S} \mathrm{cm}{ }^{-1}\right)$, and soil dry mass (\%) (log transformed and standardized). Filled square box planktivore colony transect, filled circle piscivore colony transect, Open square box, open circle respective control transects

observed in the areas close to both seabird colonies. Ryan and Watkins (1989) reported a similar relationship with increasing distance from snow petrel nest concentrations in continental Antarctica. Furthermore, within the planktivore transect, soil dry mass was negatively correlated with guano deposition; hence, water content was higher, which would further encourage vegetation development. Similar findings have been reported in other studies in both polar regions (e.g., Tatur 1989; Odasz 1994; Leishman and Wild 2001), as well as at lower latitudes (e.g., Hawke and Powell 1995; Anderson and Polis 1999; García et al. 2002; Ligeza and Smal 2003; Wait et al. 2005; Ellis et al. 2006).

Our study provides evidence that planktivore and piscivore colonies affect surrounding tundra in subtly different ways, even though the absolute amount of guano deposited per unit time or area was similar. The most striking difference was seen in phosphate ion concentration, which was up to 17 times higher near the piscivore and soil dry mass (\%) on planktivorous (P and Pc combined) and piscivorous colony transects ( $\mathrm{F}$ and $\mathrm{Fc}$ combined) colony. Soil near the planktivore colony was characterized by much lower values of $\mathrm{pH}$. The PCA analysis and detailed comparisons between the two control transects suggest that the differences observed were not related to the physical location of the two colonies. The topography of the colony-adjacent parts of each transect (first 6 sampling sites) was very similar and the amount of guano deposited also did not differ between the colonies. Moreover, there were no differences in chemical properties of the soil between the two control transects $(\mathrm{Pc}$ and $\mathrm{Fc}$ ). Thus, factors such as topography, substratum, and deposited guano amount did not significantly influence soil properties between the two types of colonies.

Rather, dietary differences between the two bird species are likely to be the main factor underlying the differences identified in their impacts on tundra soil around the two colonies (cf. Hutchison 1950; Bédard et al. 1980; Stempniewicz 2005). Much higher phosphate content is present in fish tissues in comparison with zooplankton (Andersson et al. 1988). Separately, different bacterial floras may develop on particular types of guano. As different biochemical pathways are followed, different types and proportions of biogenic salts may supply the soil in the vicinity of species- and diet-specific seabird colonies (Stempniewicz et al. 2007).

Our data showed that the rate of tundra fertilization decrease was much greater near the piscivore colony, and this was reflected in the measured physico-chemical gradients. The situation of this colony on a steep rocky cliff is likely to favor guano concentration just below the cliff. As a consequence of the more rapid decrease in rate of guano deposition, the area of the piscivore colony impact was smaller, ca. $1.2 \mathrm{~km}^{2}$ compared to the ca. $2.5 \mathrm{~km}^{2}$ of the planktivorous little auks.

Stempniewicz et al. (2007) suggested that climate warming in the Arctic will result in worsening feeding conditions for planktivorous seabirds and thus limit their populations. If occurs, a consequential decline in planktivore-influenced and increase in piscivore-influenced soils would be expected. This may lead to the soil in the vicinity of the seabird colonies having higher phosphate content and $\mathrm{pH}$ values, thus affecting tundra plant and microbial, and their dependent invertebrate. Given the spatial 
Table 3 Median values $(\mathrm{Me})$ of soil ion content ( $\mathrm{mg} 1,000 \mathrm{~g}^{-1}$ soil dry mass), $\mathrm{pH}$, conductivity $\left(\mu \mathrm{S} \mathrm{cm}^{-1}\right)$ and dry mass $(\%)$, and differences between individual transects

\begin{tabular}{|c|c|c|c|c|c|c|c|c|}
\hline \multirow[t]{2}{*}{ Parameters } & \multicolumn{6}{|c|}{ Colony versus control } & \multirow{2}{*}{$\begin{array}{l}\text { Colony versus } \\
\text { colony } \\
\mathrm{P} \leftrightarrow \mathrm{F}\end{array}$} & \multirow{2}{*}{$\begin{array}{l}\text { Control versus } \\
\text { control } \\
\mathrm{Pc} \leftrightarrow \mathrm{Fc}\end{array}$} \\
\hline & $\mathrm{P}(\mathrm{Me})$ & $\leftrightarrow$ & $\mathrm{Pc}(\mathrm{Me})$ & $\mathrm{F}(\mathrm{Me})$ & $\leftrightarrow$ & $\mathrm{Fc}(\mathrm{Me})$ & & \\
\hline $\mathrm{NH}_{4}{ }^{+}$ & 10.14 & $>$ & 0.84 & 24.35 & $>$ & 0.001 & $\mathrm{~ns}$ & $\mathrm{~ns}$ \\
\hline $\mathrm{NO}_{3}{ }^{-}$ & 56.07 & $>$ & $<0.001$ & 59.30 & $>$ & 1.48 & ns & ns \\
\hline $\mathrm{K}^{+}$ & 60.03 & $>$ & 12.14 & 84.38 & $>$ & 3.00 & ns & ns \\
\hline $\mathrm{PO}_{4}{ }^{3-}$ & 37.81 & $>$ & 0.001 & 627.74 & $>$ & 0.70 & $<$ & ns \\
\hline $\mathrm{pH}$ & 5.74 & $<$ & 7.20 & 7.46 & ns & 7.86 & $<$ & $<$ \\
\hline Conductivity & 53.35 & $>$ & 43.35 & 169.50 & $>$ & 90.35 & $<$ & $<$ \\
\hline Dry mass & 31.76 & $<$ & 78.69 & 44.72 & $<$ & 92.95 & $>$ & ns \\
\hline
\end{tabular}

Kruskal-Wallis test $(p<0.001)$, post hoc Dunn's test $(p<0.05)$; ' $<$ ', ' $>$ ' directions of significant differences; $n s$ no significant difference, $p>0.05)$. $P$ planktivorous colony transect, $F$ piscivorous colony transect, $P c, F c$ controls

distribution of suitable nesting habitat for different bird species, such a change may lead to substantial change in the biodiversity of tundra plant and animal communities. Smaller area of tundra producing lower plant biomass will limit soil invertebrate fauna development and decomposition processes, what may have also feedback effects on plants. What is more, the area may appear too small to support populations of large herbivores such as geese and reindeers, and carnivores like arctic foxes and polar bears (Stempniewicz et al. 2007; Jakubas et al. 2008; Kolb et al. 2011).

Acknowledgments This paper was supported by the Polish Ministry of Science and Higher Education (Grants No. 1883/P01/2007/32 and IPY/25/2007) and Polish-Norwegian Research Fund (Grant No. PNRF-234-AI-1/07, Alkekonge). We would like to thank Dr. Sławomira Fryderyk and Dr. Mateusz Barcikowski for assistance in data collection and lab analyses. Special thanks to Dr. Agata Weydmann and Prof. Peter Convey for their help in editing this article.

Open Access This article is distributed under the terms of the Creative Commons Attribution License which permits any use, distribution, and reproduction in any medium, provided the original author(s) and the source are credited.

\section{References}

Anderson WB, Polis GA (1999) Nutrient fluxes from water to land: seabirds affect plant nutrient status on Gulf of California islands. Oecologia 118:324-332

Andersson G, Granelli W, Stenson J (1988) The influence of animals on phosphorus cycling in lake ecosystems. Hydrobiologia 170:267-284

Bédard J, Therriault JC, Berube J (1980) Assessment of the importance of nutrient recycling by seabirds in the St. Lawrence Estuary. Can J Fish Aquat Sci 37:583-588

Bokhorst S, Huiskes A, Convey P, Aerts R (2007) External nutrient inputs into terrestrial ecosystems of the Falkland Islands and the Maritime Antarctic. Polar Biol 30:1315-1321

Brekke B, Gabrielsen GW (1994) Assimilation efficiency of adult kittiwakes and Brünnich's guillemots fed capelin and Arctic cod. Polar Biol 14:279-284
Breuning-Madsen H, Bloch Ehlers C, Borggaard OK (2008) The impact of perennial cormorant colonies on soil phosphorus status. Geoderma 148:51-54

Cocks MP, Balfour DA, Stock WD (1998) On the uptake of ornithogenic products by plants on the inland mountains of Dronning Maud Land, Antarctica, using stable isotopes. Polar Biol 20:107-111

Cygański A (1994) Chemiczne metody analizy ilościowej. Wydawnictwo Naukowo-Techniczne, Warszawa

Ellis JC (2005) Marine birds on land: a review of plant biomass, species richness, and community composition in seabird colonies. Plant Ecol 181:227-241

Ellis JC, Fariña JM, Witman JD (2006) Nutrient transfer from sea to land: the case of gulls and cormorants in the Gulf of Maine. J Anim Ecol 75:565-574

Ellis JC, Bellingham PJ, Cameron DA, Croll D, Kolb GS, Kueffer C, Mittelhauser GH, Schmidt S, Vidal E, Wait DA (2011) Effects of seabirds on plant communities. In: Mulder CPH, Anderson WB, Towns DR, Bellingham PJ (eds) Seabird islands. Ecology, invasion and restoration. Oxford University Press, New York, pp 135-176

Fischer Z, Skiba S (1993) Some remarks about bioenergetic aspects of tundra soil. Pol Polar Res 14:345-354

Galkina VN (1974) Chemical composition of soluble substances of fish-eating birds. Ekologya 5:23-28

García LV, Marañón T, Ojeda F, Clemente L, Redondo R (2002) Seagull influence on soil properties, chenopod shrub distribution, and leaf nutrient status in semi-arid Mediterranean islands. Oikos 98:75-86

Gaston AJ, Jones IL (1998) The Auks Alcidae. Oxford University Press, New York

Gilham ME (1956) Ecology of the Pembrokeshire Islands. V. Manuring by the colonial seabirds and mammals, with a note on seed distribution by gulls. J Ecol 44:429-454

Hawke DJ, Powell HKJ (1995) Soil solution chemistry at a Westland petrel breeding colony, New Zealand: paleoecological implications. Aus J Soil Res 33:915-924

Heal OW, French DD (1974) Decomposition of organic matter in tundra. In: Holding AJ, Heal OW, MacLean SF, Flanagan PW (eds) Soil organisms and decomposition in tundra. Tundra Biome Steering Committee, Stockholm, pp 279-309

Hutchison GE (1950) Survey of contemporary knowledge of biochemistry. 3. The biochemistry of vertebrate excretion. Bull Am Mus Nat Hist 96:1-554

Isaksen K (1995) Distribution of seabirds at sea in the northern Barents Sea. In: Isaksen K, Bakken V (eds) Seabird populations 
in the northern Barents Sea-source data for the impact assessment of the effects of oil drilling activity. Norsk Polarinst, Oslo, Medd, vol 135, pp 67-104

Jakubas D, Wojczulanis-Jakubas K, Walkusz W (2007) Response of Dovekie to changes in food availability. Waterbirds 30:421-428

Jakubas D, Zmudczyńska K, Wojczulanis-Jakubas K, Stempniewicz L (2008) Faeces deposition and numbers of vertebrate herbivores in the vicinity of planktivorous and piscivorous seabird colonies in Hornsund, Spitsbergen. Pol Polar Res 29:45-58

Karnovsky NJ, Kwaśniewski S, Węsławski JM, Walkusz W, Beszczyńska-Möller A (2003) The foraging behaviour of little auks in a heterogeneous environment. Mar Ecol Prog Ser 253:289-303

Kolb GS, Young HS, Anderson WB (2011) Effects of seabirds on island consumers. In: Mulder CPH, Anderson WB, Towns DR, Bellingham PJ (eds) Seabird islands. Ecology, invasion, and restoration. Oxford University Press, New York, pp 212-241

Leishman MR, Wild C (2001) Vegetation abundance and diversity in relation to soil nutrients and water content in Vestfold Hills, East Antarctica. Antarct Sci 13:126-134

Ligeza S, Smal H (2003) Accumulation of nutrients in soil affected by perennial colonies of piscivorous birds with reference to biogeochemical cycles of elements. Chemosphere 52:595-602

Mehlum F (2001) Crustaceans in the diet of adult common and Brünich's guillemots Uria aalge and U. lomvia in the Barents Sea during the breeding period. Mar Ornithol 29:19-22

Mehlum F, Hunt GL, Decker MB, Nordlund N (1998) Hydrographic features, cetaceans and the foraging of thick-billed murres and other marine birds in the Northwestern Barents Sea. Arctic $51: 243-252$

Mulder CPH, Jones H, Kameda K, Palmborg C, Schmidt S, Ellis JC, Orrock JL, Wait DA, Wardle DA, Yang L, Young H, Croll D, Vidal E (2011) Impacts of seabirds on plant and soil properties. In: Mulder CPH, Anderson WB, Towns DR, Bellingham PJ (eds) Seabird islands. Ecology, invasion and restoration. Oxford University Press, New York

Odasz AM (1994) Nitrate reductase activity in vegetation below an arctic bird cliff, Svalbard, Norway. J Veg Sci 5:913-920

Pulina M (1984) The effects of cryochemical processes in the glaciers and the permafrost in Spitsbergen. Pol Polar Res 5:137-163

Ryan PG, Watkins BP (1989) The influence of physical factors and ornithogenic products on plant and arthropod abundance at an Inland Nunatak group in Antarctica. Polar Biol 10:151-160

Rønning OI (1996) The flora of Svalbard. Norwegian Polar Institute, Troms $\emptyset$
Smith VR, Froneman PW (2008) Nutrient dynamics in the vicinity of the Prince Edward Islands. In: Chown SL, Froneman PW (eds) The prince Edward Islands. Land-sea interactions in a changing ecosystem. SUN Press, Stellenbosch, pp 165-179

Stempniewicz L (1990) Biomass of Dovekie excreta in the vicinity of a breeding colony. Colon Waterbirds 13:62-66

Stempniewicz L (1992) Manuring of tundra near a large colony of seabirds on Svalbard. In: Opaliński KW, Klekowski RZ (eds) Landscape, life world and man in the High Arctic. IE PAN Press, Warszawa, pp 255-269

Stempniewicz L (2001) Alle alle little Auk. BWP update. J Birds West Palearct 3:175-201

Stempniewicz L (2005) Keystone species and ecosystem functioning. Seabirds in polar ecosystems. Ecol Quest 6:111-115

Stempniewicz L, Błachowiak-Samołyk K, Węsławski JM (2007) Impact of climate change on zooplankton communities, seabird populations and arctic terrestrial ecosystem-a scenario. DeepSea Res 54:2934-2945

Strøm H (2005) Brünnich's guillemot Uria lomvia; Kittiwake Rissa tridactyla; little Auk Alle alle. In: Kovacs KM (ed) Birds and mammals of Svalbard. Norwegian Polar Institute, Troms $\varnothing$

Tatur A (1989) Ornithogenic soils in the maritime Antarctic. Pol Polar Res 10:481-532

ter Braak CJF, Šmilauer P (2002) CANOCO Reference manual and user's guide to Canoco for Windows: software for canonical community ordination (version 4.5). Microcomputer Power. Ithaca, New York

Wainright SC, Haney JC, Kerr CA, Golovkin N, Flint MV (1998) Utilization of nitrogen derived from seabird guano by terrestrial and marine plants at St. Paul, Pribilof Islands, Bering Sea, Alaska. Mar Biol 131:63-71

Wait DA, Aubrey DP, Anderson WB (2005) Seabird guano influences on desert islands: soil chemistry and hernaceous species richness and productivity. J Arid Environ 60:681-695

Zmudczyńska K, Zwolicki A, Barcikowski M, Barcikowski A, Stempniewicz L (2009) Spectral characteristics of the Arctic ornithogenic tundra vegetation in Hornsund area, SW Spitsbergen. Pol Polar Res 30:249-262

Zmudczyńska K, Olejniczak I, Zwolicki A, Iliszko L, Convey P, Stempniewicz L (2012) Influence of allochtonous nutrients delivered by colonial seabirds on soil collembolan communities on Spitsbergen. Polar Biol 35:1233-1245 